\title{
ADRIAN EVANS AND CRITICAL PEDAGOGY: HIS EARLY CAREER
}

\section{Professor MaryAnne Noone, La Trobe \\ University, Australia}

I was delighted to accept the invitation to be a part of Professor Adrian Evan's Festschrift in November 2018 because over the last thirty years Adrian and I have journeyed together along the social justice and clinical legal education path, sharing many challenges, discoveries, losses and adventures.

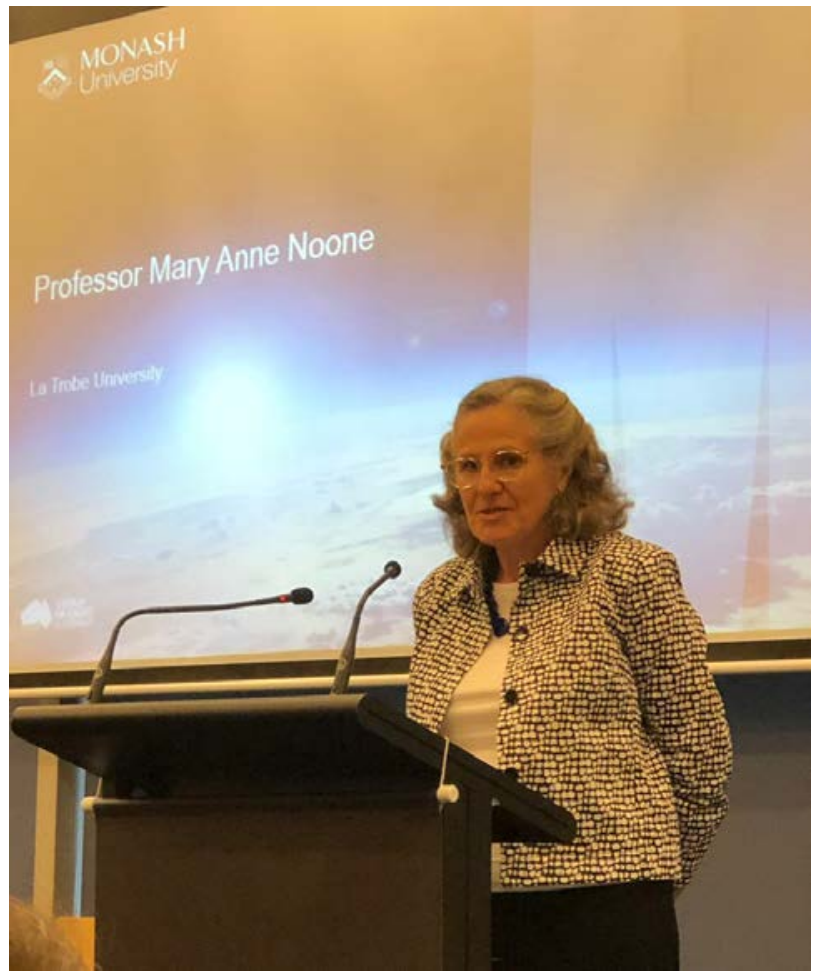

Specifically I have been asked to discuss Adrian's early contribution to clinical legal education but to do this it is necessary to also focus on his contribution to the community legal centres. In Australia, like many other countries (as detailed in Frank Bloch's book) early clinical legal education programs were intertwined with the developing community legal centres or neighbourhood law centres movement. ${ }^{1}$

In fact in the first part of Adrian's career, his contribution relates more to community legal centres than to academic pursuits. However having noted that, from early on, Adrian's actions and writings reveal a clear and strong commitment to a philosophy of education

\footnotetext{
${ }^{1}$ Bloch F. \& Noone M.A, (2010), 'Legal Aid Origins of Clinical Legal Education' in Bloch F.(ed) The Global Clinical Movement: Educating Lawyers for Social Justice Oxford University Press; Noone M.A. (1997), 'Australian Community Legal Centres - The University Connection' in Cooper J. \& Trubek L. (eds), Educating for Justice: Social Values and Legal Education, Dartmouth
} 
which has endured throughout his working life: critical pedagogy. I draw this out in this paper, drawing on my own archives as well as rereading Adrian's early publications. These were not refereed academic articles but pieces in the Legal Services Bulletin ${ }^{2}$ and Hearsay ${ }^{3}$.

I will focus on a couple of examples that reveal Adrian is, and always has been, an agitator, a disrupter and an innovator, someone prepared to challenge the status quo and propose alternative approaches to legal education, to the operation of community legal centres and to the regulation of the legal profession.

But first a little background.

Adrian studied law and commerce at Melbourne University, graduating in 1972. This was at the time that the Whitlam Labor Government came to power in Australia with a election theme of 'It's time for change'. ${ }^{4}$ A progressive government was elected after 23 years of conservatism. Globally and domestically it was a time of significant social disruption and change.

Although there was changes in many aspects of society, this was not necessarily the case in the legal profession. As David Neal notes, for a law graduate at this time, "options like working for a legal aid commission, a public interest law practice, a law reform commission, in the pro bono program at one of the big law firms, or even volunteering at a community

\footnotetext{
2 The Legal Service Bulletin, an initiative of the Fitzroy Legal Service, was a newsletter then journal, that aimed to provide a medium for the distribution of educational material and general information relating to legal aid in

Australia. It became the Alternative Law Journal in 1992. See Brown D.,' A Critique of the Legal Service Bulletin' in Neal D., On tap not on top: Legal Centres in Australia 1972-1982 Legal Service Bulletin p40-48 ${ }^{3}$ Hearsay was the newsletter of the Federation of Community Legal Centres (Victoria) from 1985- 1998.

${ }^{4}$ Neal D., 'Law and Power- living in the 70s' (2014) Law in Context 99, 101
} 
legal centre did not exist. It was a much narrower legal world." ${ }^{5}$ Consequently Adrian pursued the traditional path of completing his articles ${ }^{6}$ and he then worked in the tax department at Price Waterhouse \& Co. - Chartered Accountants for a short time.

However in a move that was to characterise Adrian's career, he took on an unconventional position. He became the legal advisor to student volunteers who were giving free legal advice at the Monash university student union. ${ }^{7}$ Then in 1976 he was appointed by the Students Representative Council at La Trobe University to establish an in-house legal service for students of the university. La Trobe University was a young university (commenced in 1967) with quite a reputation for student activism and innovative academic programs. ${ }^{8}$

This was a time of radical change in the provision of legal services in Australia and elsewhere: the first Aboriginal Legal Service opened in 1971, the first community legal service Fitzroy Legal Service opened in December 1972 quickly followed by a number of other community legal centres in Victoria. These voluntary, independent, community run organisations offered free legal assistance, out of office hours, in 'shop front' locations. It is hard for us to imagine now, but these services were, at the time, seen as an serious affront and perceived by many as a threat to, the existing conservative legal profession..$^{9}$ In taking up this position

\footnotetext{
${ }^{5}$ Neal above

${ }^{6}$ Law graduates had to complete a year long period of 'apprenticeship' under the supervision of a legal practitioner before becoming admitted to legal practice. This was called articles.

${ }_{7}$ Giddings J., Promoting Justice through Clinical Legal Education (2013) Justice Press pp 171 - 189

${ }^{8}$ La Trobe University, From the Paddock to the Agora (2017) La Trobe University Press in conjuction with Black Inc ; Neal note 2 pp 112-118

${ }_{9}^{9}$ Noone M.A. (2001), 'The Activist Origins of Australian Community Legal Centres' (19) Law in Context 128; Noone M.A. \& Tomsen S., Lawyers in Conflict: Australian Lawyers and Legal Aid (2006) Federation Press 69-72, $199-230$
} 
at La Trobe University student union, Adrian was throwing his hat into the alternative/progressive ring.

Simultaneously Adrian was studying theology at the Australian College of Theology, and playing an active role in his church. I surmise that Adrian's religious beliefs may have also prompted him to become involved in improving access to justice rather than assisting the rich with their tax issues.

In his role at the La Trobe University student union, Adrian was advising and providing legal services to students with a particular emphasis upon assisting students facing disciplinary issues but he soon realised the demand was more than he could meet. At the university campus there was a Department of Legal Studies focused on taking an interdisciplinary approach to the study of law. ${ }^{10}$ Adrian approached the Department and requested they allow him to 'co-opt' the students on the basis that he would train them 'on the job' in basic legal skills. He was given approval and in 1978 a subject was established integrating this training into the La Trobe Bachelor of Arts. ${ }^{11}$

This was Adrian's first foray into clinical legal education and is an early example of Adrian identifying a problem and creatively devising a solution. He was unable to address the student demand for legal services and so proactively sought to train students to work as paralegals assisting him. But this was not just a technical skills based course.

\footnotetext{
${ }^{10}$ Petersen, K. Socio-legality and La Trobe University : introducing and celebrating a broad church of ideas. (2013) 29 (2) Law in Context,1-9; DaviesS, S. From law to 'legal consciousness' : a socio-legal pedagogical expedition.. (2013) 29 (2) Law in Context, 42-58.

${ }^{11}$ Evans, A., ‘Para-legal training at LaTrobe' (1978) 3 Legal Service Bulletin 65
} 
Innovatively, Adrian engaged with the counselling service on campus to assist him in preparing the students for these roles and teaching interviewing skills to the students. In this endeavour we see the seeds developing of Adrian's philosophy of education as indicated in one of his first written pieces in 1978

"On the premise that education is the fruit of human interchange rather than an exercise in role definition [my emphasis], first year students from the Department of Legal Studies are invited to apply for a half unit para-legal training programme" ${ }^{12}$

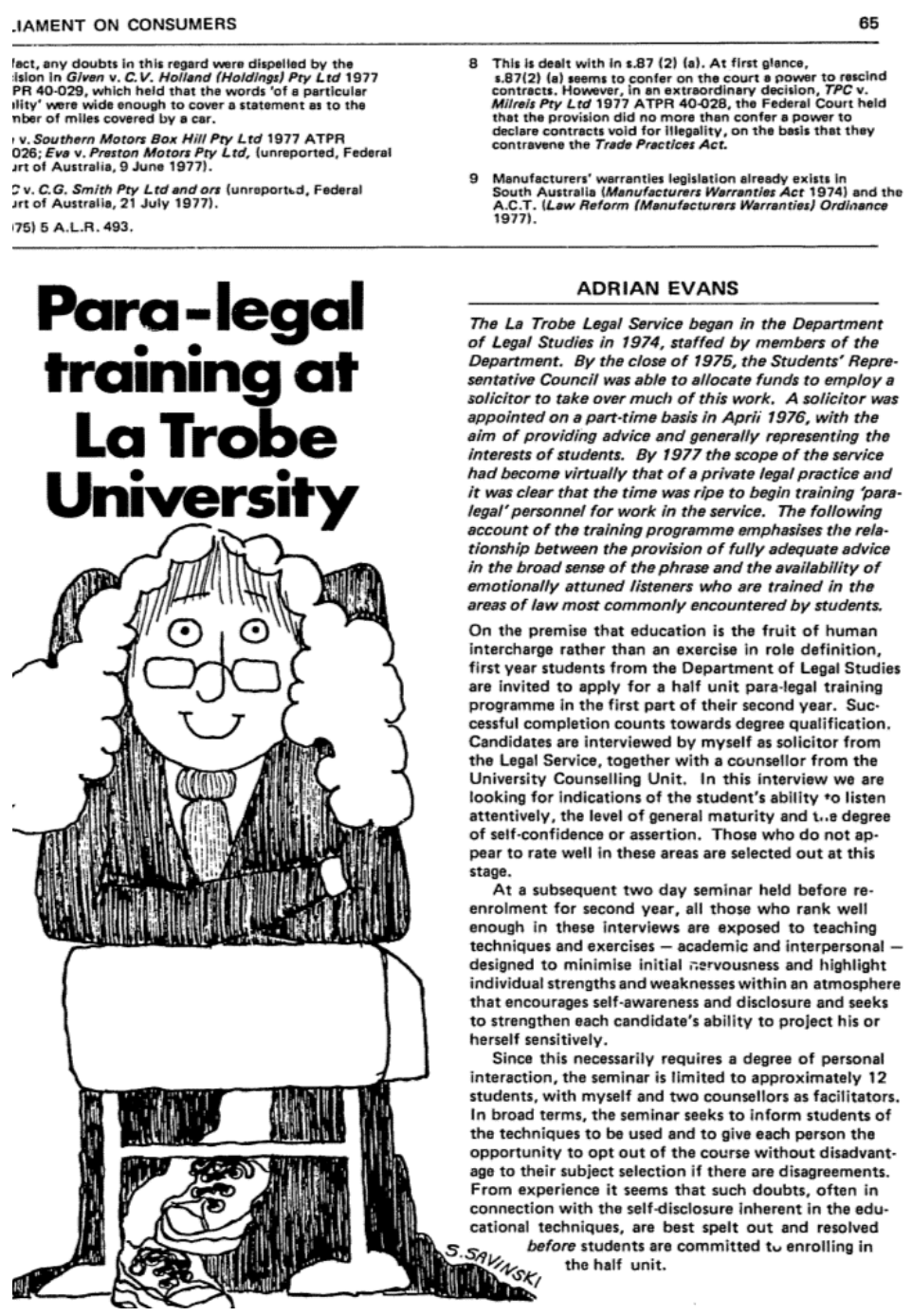

12 Evans, A., ‘Para-legal training at LaTrobe' (1978) 3 Legal Service Bulletin 65 
Over a 10 year period, Adrian established a group of paralegals specialising in representing students before the University's disciplinary tribunals. The utilisation of paralegals was unconventional at that time and is an illustration of Adrian's preparedness to challenge the status quo. ${ }^{13}$ Based on this experience, in 1989, when legal aid funding was being cut, Adrian controversially suggested having paralegals rather than lawyers as front line advisers. ${ }^{14}$

Of course whilst all this was happening at LaTrobe, Adrian was also the father of 4 young boys, including twins (see Maria's contribution).

In May 1985, I commenced working at La Trobe university in a unique position as a lecturer practising as a lawyer at another community legal service close to campus; West Heidelberg Community Legal Service. As part of that role I was responsible for a subject called Law and Social Justice in which students undertook placements at the legal service. ${ }^{15}$

A month after starting in the position (June 1985) I attended the National community legal centres conference in Brisbane. I have a strong recollection of wandering home from dinner with group of conference attendees, when Adrian and I got chatting about the theme of the conference, social change. He suggested we might work together - we could revise his subject to more directly focus the curriculum on social change. This was the beginning of my clinical journey and working together with Adrian. Although I had worked at Springvale

\footnotetext{
${ }^{13}$ For further contemporary discussion see: Noone M.A. (1991), 'Paralegals - in the Community's Interest?' in Vernon J. \& Regan F. (Eds), Improving Access to Justice Australian Institute of Criminology Noone M.A. (1988), 'Paralegals - a growth area in times of restraint?' 13 Legal Service Bulletin 253

${ }^{14}$ Evans, A, 'Para-Legal Advisors!' (1989) 19 Hearsay 5

${ }^{15}$ See Dickson, J., ' 25 Years of Clinical Legal Education at La Trobe Uni: Keeping the community in legal education' (2004) 29 Alternative Law Journal 37; Neal D., 'Law and Power- living in the 70s' (2014) Law in Context 99, 101
} 
Community Legal Service, which had a clinical program with Monash University, I had been the community lawyer and had no direct responsibility for students. ${ }^{16}$ Looking back, I probably had more experience with activism, having been the lawyer for the squatters union $^{17}$, whereas Adrian had developed a sophisticated clinical program at the SRC. He recognised the potential of bringing these two aspects together.

Working together, we developed a most ambitious and exciting course. The subject went for a full year, students spent time on placement at both our respective legal services. The original University Handbook entry for the subject stated:

'the aim of the subject is to produce students with firsthand experience of community legal services and a priority for social action, together with the strategies for implementation developed within the reality of client contact and the opportunities now being provided with the legal system. The approach is to link clinical skills, substantive law, research, exposure to case work environments and the technique of public interest legal analysis and strategies" [my emphasis]

\footnotetext{
${ }^{16}$ Greenwood K., It seemed like a good idea at the time : a history of Springvale Legal Service 1973-1993 (1994) Springvale Legal Service

${ }^{17}$ Noone M.A., Stewart I., Trezise P., \& Winn G. (1983), 'Bona Vista-A Large and Attractive Property' 8 (6) Legal Service Bulletin 253
} 
Teaching this course with Adrian, I learnt about the Binder and Price approach to legal interviewing skills ${ }^{18}$, the Myers-Briggs Type Indicator ${ }^{19}$, utilising Structural Analysis to strategise about social problems ${ }^{20}$, theories of non-violent action ${ }^{21}$ and much more. ${ }^{22}$

Adrian's philosophy of education pervaded many aspects of the course. He drew on the work of Ivan Illich ${ }^{23}$ and Paulo Friere ${ }^{24}$ and shunned a 'banking' concept of education. He was clearly an advocate of 'critical pedagogy'. ${ }^{25}$

To quote Wikipedia,

Advocates of critical pedagogy view teaching as an inherently political act, reject the neutrality of knowledge, and insist that issues of social justice and democracy itself are not distinct from acts of teaching and learning. ${ }^{[2]}$ The goal of critical pedagogy is emancipation from oppression through an awakening of the critical consciousness, When achieved, critical consciousness encourages individuals to effect change in their world through social critique and political action. $^{26}$

\footnotetext{
${ }^{18}$ Binder D. \& Price S., Legal Interviewing and Counselling: a client centred approach (1977) West Academic Publishing USA

${ }^{19}$ https://www.myersbriggs.org/my-mbti-personality-type/mbti-basics/home.htm?bhcp=1; Peters, Don, \& Peters, Martha M. (1990). Maybe that's why I do that: Psychological type theory, the Myers-Briggs type indicator, and learning legal interviewing. New York Law School Law Review, 35(1), 169-198.

${ }^{20}$ Reid, S., Change for justice : structural analysis and strategies for change (1987) Uniting Church (Victorian Synod) in conjunction with Centre for Structural Analysis

${ }^{21}$ Burrowes, R., The Strategy of Nonviolence Defense: A Gandhian Approach (1996) Albany, NY: State University of New York Press, .

${ }^{22}$ Notes from the course detail guest lecturers from range of related organisations as well as legal aid, community legal centres, police force etc.

23 Illich, I, Disabling professions (1977); Deschooling Society (1973)

${ }^{24}$ Friere, P., Pedagogy of the Oppressed (1970) [English version]

${ }^{25}$ For a detailed explanation see entry here Coghlan, D., \& Brydon-Miller, M. (2014). The SAGE encyclopedia of action research (Vols. 1-2). London, : SAGE Publications Ltd doi: 10.4135/9781446294406

${ }^{26}$ https://en.wikipedia.org/wiki/Critical pedagogy
} 
I think anyone who has worked with Adrian, will recognise how this approach has underpinned his attitude to legal education and provided the foundation for much of the work of his career.

At the same time as Adrian was working a La Trobe, he was actively engaged in the Community Legal Centres sector and the Federation of Community Legal Centres. In 1985, Adrian took on responsibility for establishing a mutual professional indemnity insurance scheme all Victorian Community Legal Centres. This scheme became the template for the national scheme after he oversaw a related Commonwealth government funded consultancy. ${ }^{27}$

Whilst working on the insurance issue, which was aimed at enhancing the longevity of community legal centres, Adrian published an article titled "A Challenge to Community Legal Centres". ${ }^{28}$ Community legal centres in Victoria were celebrating 15 years of existence but Adrian was not about to wish those working in centres Happy Birthday, instead he said:

Community legal centres are in a mid-life crisis which could see them decline in impact in much the same way as many males do. Collectively and at individual level some real soul searching is necessary if the impetus of the 1970s is to be recovered by the majority of centres. The process must include the motivational regeneration of workers, the education and empowerment of the client groups they serve and the

\footnotetext{
${ }^{27}$ Evans, A 'Community and Aboriginal Legal Centres - National professional indemnity insurance options for 1988' 1987) 12 Legal Service Bulletin 277 ; Evans, A, 'Professional Indemnity Insurance for Legal Centres' 1987 (9) Hearsay 12

${ }^{28}$ Evans A., 'A challenge to community legal centres' 1987 (12) Legal Service Bulletin 165
} 
development of investigative, analytical and strategic techniques at the price of lower time inputs into routine case work. [my emphasis]

In this article Adrian is challenging those working in community legal centres to adopt aspects of critical pedagogy; to work towards social justice to both achieve political relevance as well as having personal integrity; he talks of education and empowerment of the community; and he encourages workers to use not only individual litigation but consider mediation and non-violent disobedience.

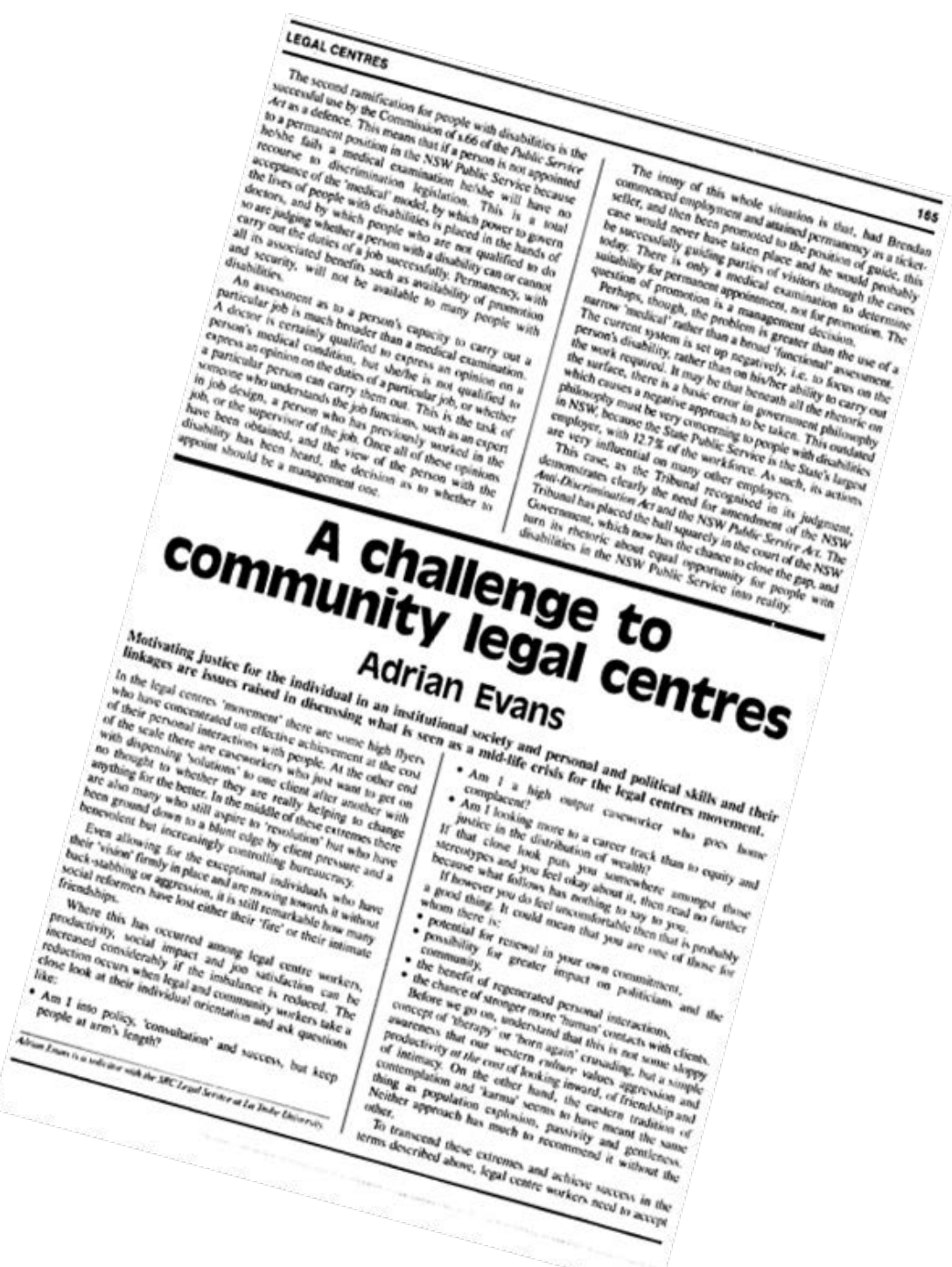


Adrian did not hold back in this article - it is highly provocative:

Only by grasping the nettle of identification with the oppressed will centres lose their Cinderella fragility and recover the idealism with which they were founded such a short time ago. If we wallow much longer in the comfort of acceptance by the established profession, or in the warmth of the wages and conditions spa bath, political legitimacy will be handed over to less conservative groups and growing irrelevancy will tighten like a noose on the energy and output of our workers. ${ }^{29}$

Adrian's challenges were subsequently discussed at the 1987 National community legal centre conference in Hobart, Tasmania which itself was a controversial affair. The Conference had tried to confront the "fundamental issues' raised in Adrian's article and challenged the community legal centre movement to define its role in addressing poverty. ${ }^{30}$ Many of the issues Adrian identified in 1987 have been revisited, albeit in less direct terms, many times in the intervening years. ${ }^{31}$

Unfortunately Adrian and I only taught the Clinical Legal Education course together for one year (1987) however the subject continued to be taught by myself and my colleague Judith Dickson for several years and many aspects of the pedagogy underpinning the contents and approach continued into the clinical legal education program at La Trobe University.

\footnotetext{
${ }^{29}$ P 169

30 Farrelly, S., 'Reflections on the 1987 Community Legal Centres Conference' (1987) Legal Service Bulletin 227

${ }^{31}$ Rich N., Reclaiming Community Legal Centres: Maximising our potential so we can help our clients realise theirs (2009) Consumer Action Law Centre and Victoria Law Foundation; Rice S., 'Are CLCs finished?' (2012) 37(1) Alternative Law Journal 17; Noone M.A. (1992), 'Imperatives for Community Legal Centres',17 Alternative Law Journal 121
} 
In 1988 Adrian moved to the position of Coordinator of the Springvale Legal Service and Lecturer in Law at Monash University where he joined Australian clinical pioneers Sue Campbell and Guy Powles. ${ }^{32}$ Now he was in charge of a large community legal service and the related clinical legal education program. Although Adrian continued to have a role in community legal centres (he was on the executive of the Federation of Community Legal Centres in $1989^{33}$ ) including continuing to offer a critical perspective ${ }^{34}$, his focus shifted more towards legal education and research.

However Adrian's commitment to critical pedagogy did not diminish. In an article he wrote in 1990 titled 'Developing socially responsible lawyers' he again spoke of the difference between the 'ladder' or linear approach to teaching (conventional) compared to the "participatory 'web' approach 'where both 'teacher' and students interact around the context of real clients' situation. In this article Adrian strongly asserts, 'critical' or 'liberating' education is the only method that works well in clinical environments, ${ }^{35}$ and that clinical legal education can only reach its full social and educative potential in a community environment. ${ }^{36}$

\footnotetext{
${ }^{32}$ Giddings J., Promoting Justice through Clinical Legal Education (2013) Justice Press pp 171 - 189

${ }^{33}$ Federation of Community Legal Centres Annual Report 1989

${ }^{34}$ Evans, A. 'The Leadership of CLCs - letter to Editor' (1991) 32 Hearsay 15

${ }^{35}$ Evans A., 'Developing socially responsible lawyers' ( (1990) 15 Legal Service Bulletin 218

${ }^{36}$ This article also is an illustration of Adrian's preference for setting out his ideas in diagrammatic form.
} 


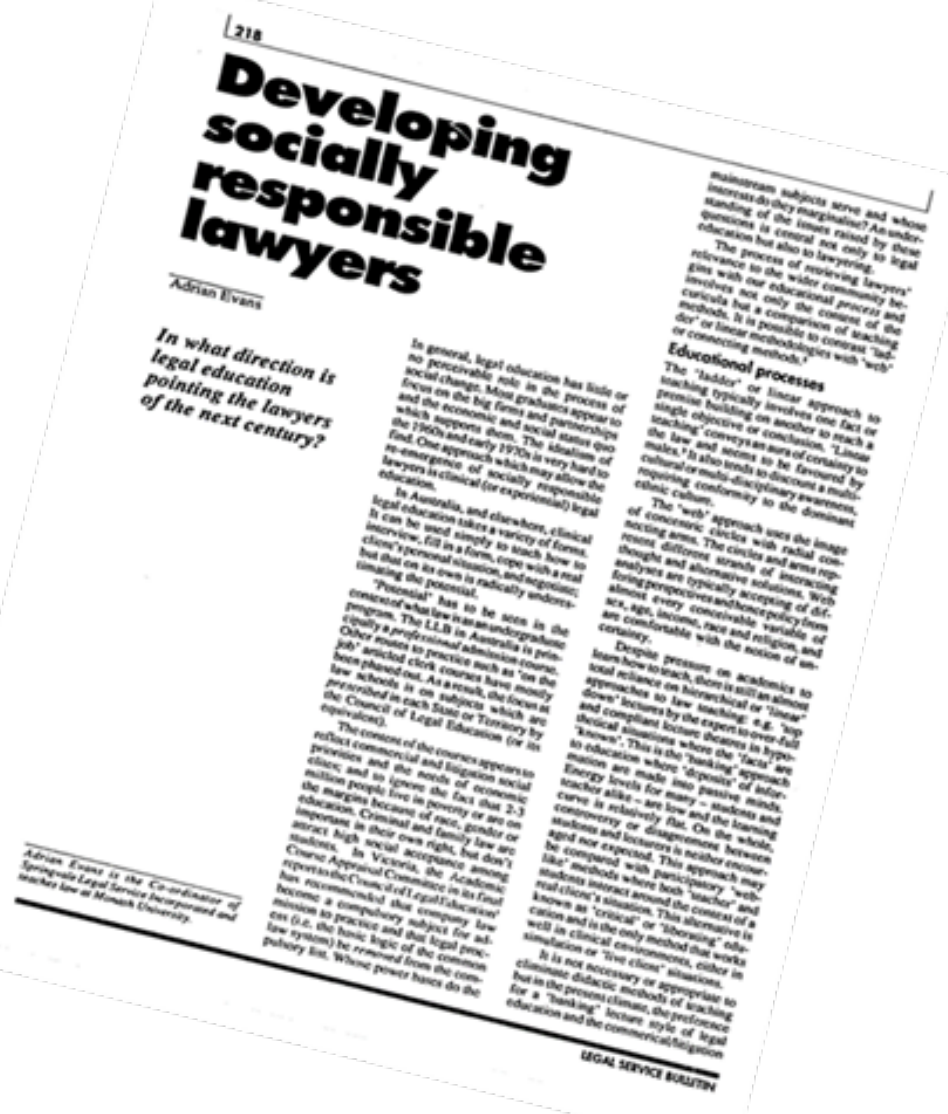

Developing socially responsible lawyers
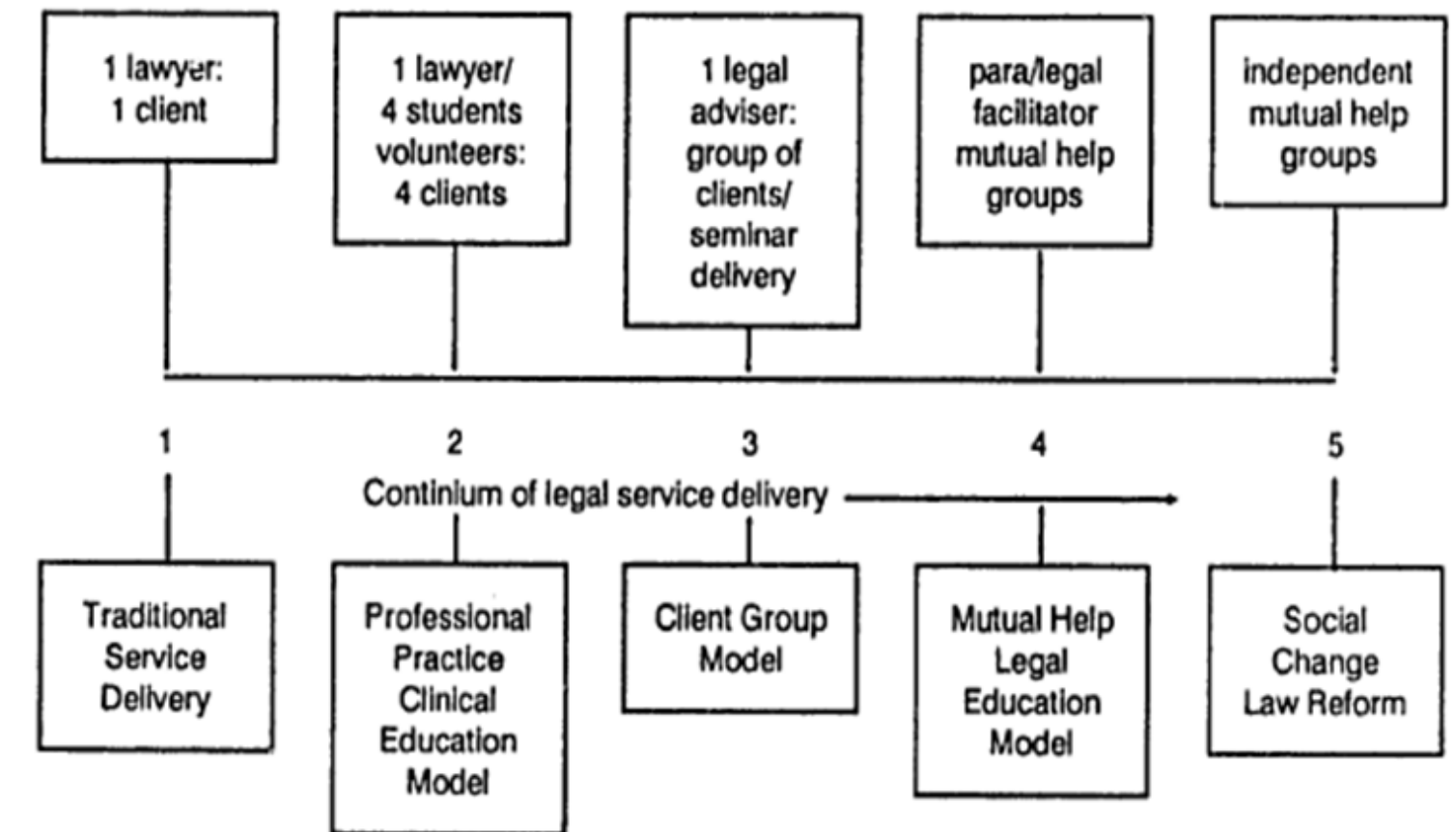

Options in delivering Legal Services 
Although Springvale Community Legal Service had been involved in range of community projects, these did not involve the law students. Putting his theory into practice, Adrian quickly developed a community development component to the clinical legal education program, where students would work on projects with community groups. ${ }^{37}$ As Giddings notes, Adrian together with Springvale staff, Roy Reekie and Phillip Somerville, were "heavily influenced by Brazilian educator Paulo Friere's writings on the concept of 'dialogical empowerment' with students engaged in a process of mutual enquiry with their teacher. Adrian saw the role of 'close facilitative supervision' as critical. ${ }^{38}$

In the role at Springvale and Monash, Adrian begins taking a key leadership role in Australian clinical legal education and establishing an international network of clinicians and legal ethicists. ${ }^{39} \mathrm{He}$ is asked to assist in the establishment of new programs around Australia and had a role in convincing the Commonwealth government to fund four clinical programs around the country. ${ }^{40}$

In April 1990, he organised the first national clinical legal education conference titled "Australian Clinical Legal Education in the 1990s". ${ }^{41}$ The conference was held the day before the National Community Legal Centre conference illustrating the continuing close links

\footnotetext{
${ }^{37}$ Giddings J., above pp 189 - 190

${ }^{38}$ Giddings above

${ }^{39}$ For example Adrian attended the Third International Conference on Clinical Legal Education in July 1993. Evans, A., 'Clinical Legal Education and Justice Entwined' (1993) 18(5) Alternative Law Journal 237 and he was active in the formation of the Global Alliance for Justice Education : https://www.gaje.org/

${ }^{40}$ Giddings J., Promoting ...... p 191-192; Giddings, Jeff --- "Legal Education: The Commonwealth discovers clinical legal education" (1998) 23(3) Alternative Law Journal 140

${ }^{41}$ There had been an 'Australian Clinical Legal Education Teachers Conference' in February 1987 organised by Monash Faculty of Law.
} 
between Australian clinical programs and community legal centres. Conference topics included 'discussion on the 'type' of lawyers which present programs seek to produce and developing socio-legal awareness of clients.

Adrian's presentation at the conference was titled "structural factors giving the context to legal education'. Again he talked of "the participatory 'web-like' paradigm of clinical teaching compared to the hierarchical/ladder like methods of didactic teachers".

I referred at the start to my concurrent clinical journey with Adrian. In 1991, we did literally embark on a clinical expedition. Together we visited 25 'peak' or 'best practices' clinical legal education programs in north America over a four week period. Adrian had received a grant from the Monash Development fund to address recommendations for the future of the Monash clinical program and I was on sabbatical. We were fortunate to meet with many of the 'wise' men and women of American clinical legal education.

These photos include - Haywood Burns at Cuny, Steve Wizner at Yale, Fred Zemans at Parkdale/Osgoode Hall, Rick North at University of Maryland, Jeff Hartje, University of Denver University.. 


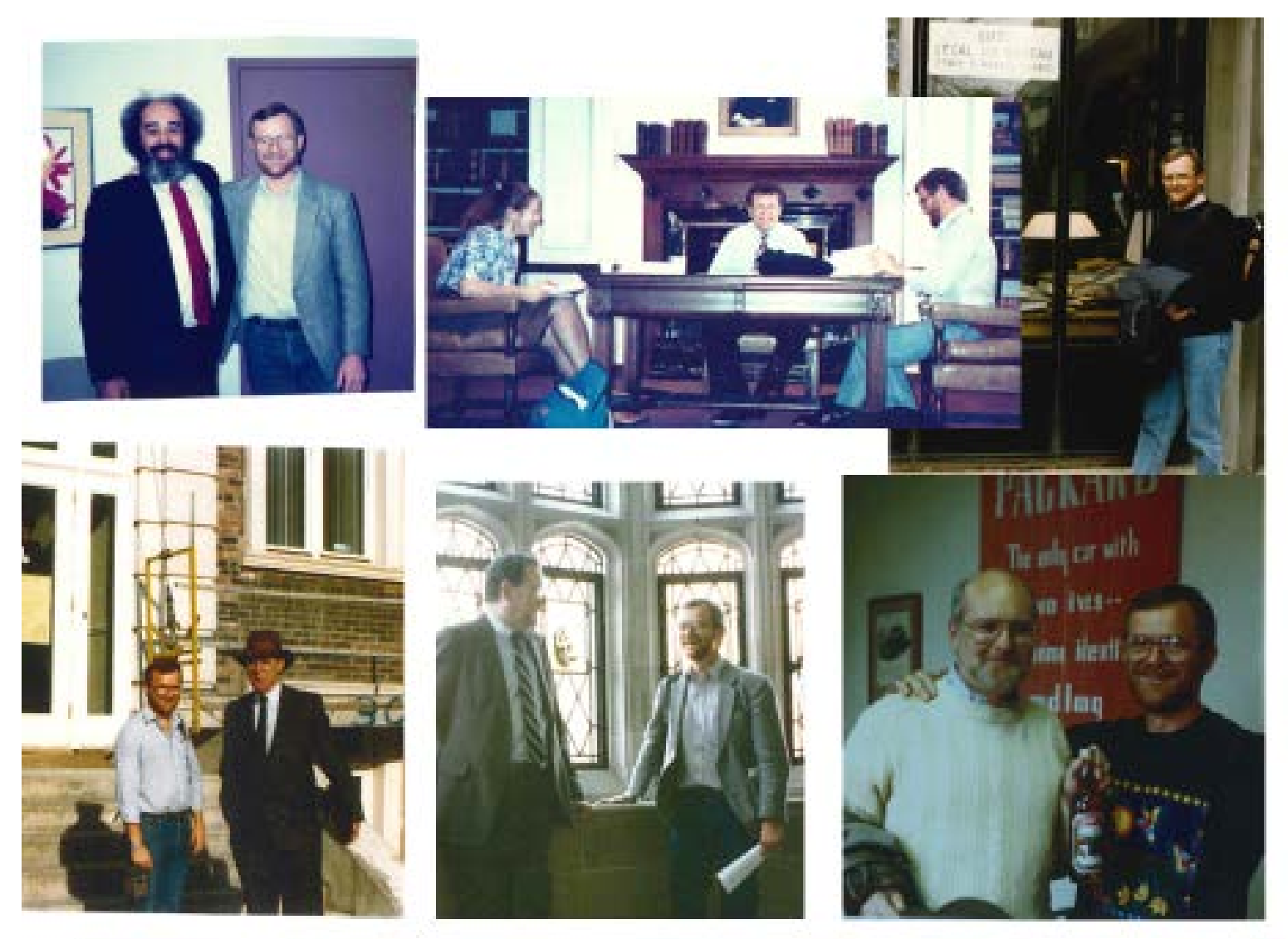

A strand of Adrian's career is his interest in technology. He was and still is an early adopter of new technology. At Springvale he was responsible for planning and implementation of successive generations of computerised client case management software, commencing in 1988 with the conversion of existing Macintosh to IBM based word processing and continuing in 1989 with the design, supervision and marketing of a customised client information system for file and statute of limitation management, student supervision, research and statistical reporting purposes. So as part of this trip we not only learnt about the innovative curriculum developments we also explored the latest in technology and physical clinical environments. 
I think for both of us this was a formative experience. In visiting a range of clinical legal education programs, we were able to appreciate the soundness of Australian clinical legal education, however we came back to Australia wanting to establish more focussed or specialised clinical legal education programs. I developed a clinical legal ethics course ${ }^{42}$ and Adrian, the Sexual Assault Clinic (see Carolyn Worth's contribution). ${ }^{43}$

Around this time, Adrian also starts to crank up his analysis and criticism of aspects of the legal profession - there was a community group project at Springvale based around people with complaints against lawyers. One of his first research projects was to survey people's opinions of lawyers. ${ }^{44} \mathrm{He}$ also begins to take an interest in solicitors trust accounts and enrols in a Masters of Laws. ${ }^{45}$ Other speakers will develop these themes.

Adrian was also increasingly involved in law reform and participating on various advisory groups both with government and for non-government organisations. As an example in 1989 he worked with others from the Federation of Community Legal Centres on a submission to a Senate Standing Committee of Legal and Constitutional Affairs enquiry into the Costs of Legal Services and Litigation. Adrian made a particular contribution to the section on the

\footnotetext{
${ }^{42}$ Noone M.A \& Dickson J. (2002) 'Teaching towards a new professionalism: Challenging law students to become ethical lawyers' 4 (2) Legal Ethics 127

${ }^{43}$ Evans A., 'Specialised clinical legal education begins in Australia' (1996) 21(2) Alternative Law Journal 70

${ }^{44}$ Evans A., 'Acceptable But Not Entirely Satisfied: Client Perceptions of Victorian Solicitors' (1995) 20

Alternative Law Journal 57-62; 'A Concise History of the Solicitors Guarantee Fund (Vic): A Marriage of Principle and Pragmatism' (200) Monash University Law Review,??; ‘Professional Ethics North and South: Interest on Client Trust Funds and Lawyer Fraud - An Opportunity to Redeem Professionalism'(1996) 3 International Journal of The Legal Profession 281-300

${ }^{45}$ Evans A., 'Whose Money? The Solicitors Guarantee Fund', (1993) 18 Alternative Law Journal 220-225
} 
regulation and ethics of the legal profession, an area he become an international expert on again others will pick up this theme.

THE AGE, Monday 16 July 1990

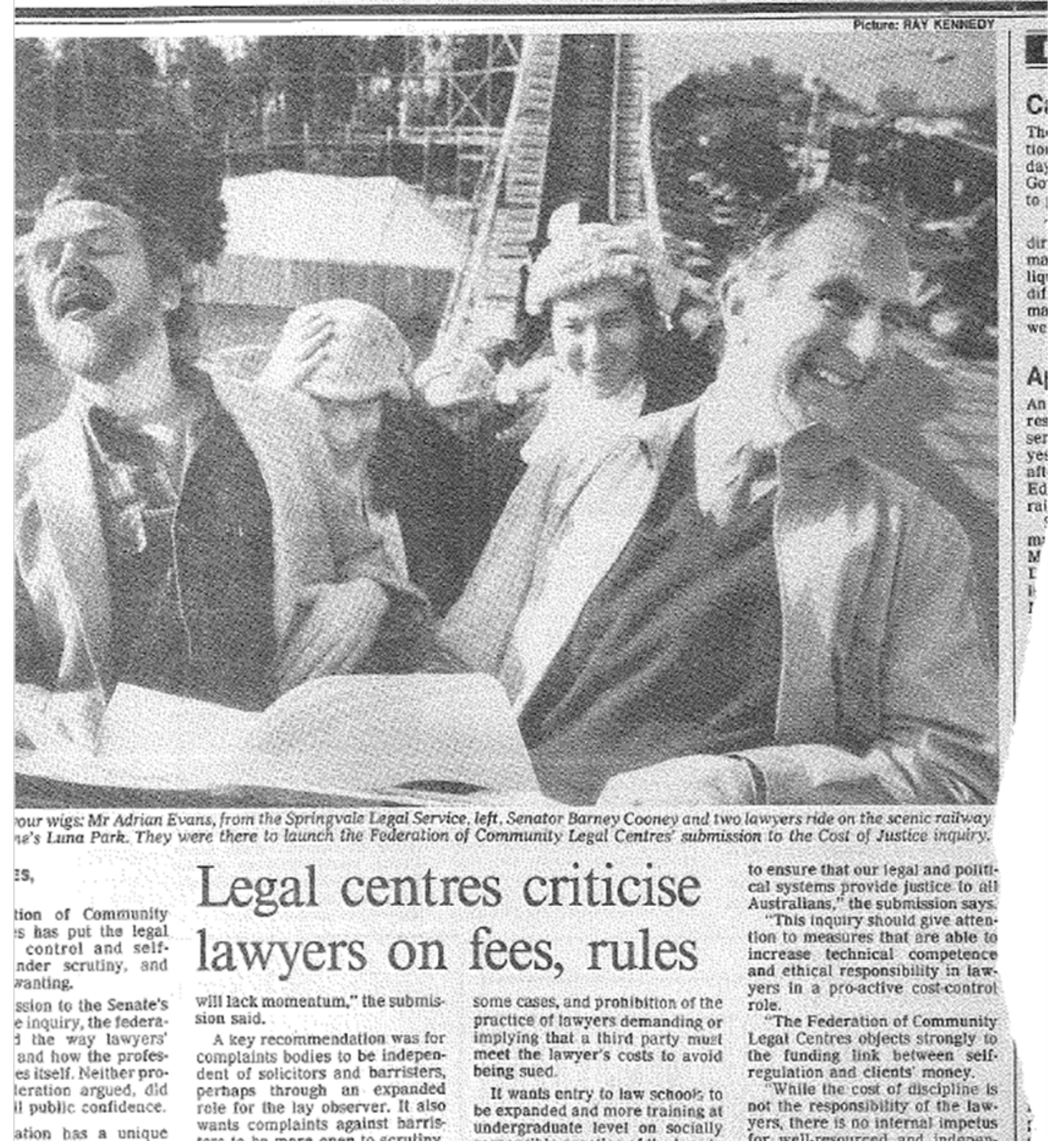

So to conclude I want to show a photo taken at Luna park ${ }^{46}$ at the launch of the Federation of Community Legal Centre's submission to the Senate inquiry into Cost of Legal Services

${ }^{46}$ Fun parlour at StKilda, Victoria Australia https://lunapark.com.au/ 
and Liltigation. Adrian is sitting with the chair of the committee, Senator Barney Cooney and in the background are several legal centre workers. At the time of this photo, 1989, Adrian academic career it about to take off - he will go on to complete a Masters of Law, a PhD, become a professor and author several books. ${ }^{47}$

From the examples I have discussed, we can see that Adrian has been prepared to take risks and be unconventional in his approach. He is someone prepared to challenge and disrupt the status quo. He is an agitator and innovator.

More than three decades ago Adrian adopted a particular approach to teaching, critical pedagogy and this has grounded his involvement in clinical legal education. He is firmly committed to creating deep and transformative learning experiences for students in the furtherance of social justice. ${ }^{48}$

I feel very fortunate to have shared aspects of Adrian's journey through community legal centres and clinical legal education. In my experience, Adrian is a person of great integrity and sound values. He is someone who has sought to practice what he preaches. He an

\footnotetext{
${ }^{47}$ Evans, A. H., Cody, A., Copeland, A., Giddings, J. M., Joy, P., Noone, M. A. \& Rice, S., Australian clinical legal education: Designing and operating a best practice clinical program in an Australian law school (2017) 1st ed. The Australian National University; Parker, C. E. \& Evans, A. H., Inside Lawyers' Ethics (2017) $3^{\text {rd }}$ ed Cambridge University Press; Hyams, R. L., Campbell, S. L. \& Evans, A. H., Practical Legal Skills: Developing Your Clinical Technique (2014), $4^{\text {th }}$ ed. South Melbourne, Victoria, Australia: Oxford University Press; Evans A.H., The Good Lawyer, (2014), Port Melbourne, Victoria, Australia: Cambridge University Press. 232; Evans A., Assessing lawyers' ethics: A practitioners' guide, (2011), 1st ed. New York NY USA: Cambridge University Press.

${ }^{48}$ Evans, A., 'Client Group Activism and Student Moral Development in Clinical Legal Education' (1999) 10 Legal Education Review 179
} 
exemplar of a 'good lawyer'49. It has been a privilege, Adrian, to share experiences and collaborate on projects throughout your career, particularly those in the early stages.

${ }^{49}$ Evans A, The Good Lawyer (2014) Cambridge University Press 